were hypertrophied and showed inflammatory exudation but there was no evidence of tubercle.

CASE 11. The patient was aged two years. The postmortem condition was as follows. There were old caseous thoracic glands with acute general tuberculosis. Both tonsils were bealthy.

CASE 12 - The patient was aged one year. The postmortem condition was as follows. There were old tuberculous thoracic glands with acute general tuberculosis and some miliary tubercles in the right cervical glands. The left tonsil was hypertrophied and under the microscope typical giant cells were seen. Giant cells were also present in the right tonsil but no bacilli were found. The infection here was secondary to the tubercle of the thoracic glands.

CASE 13.-The patient was aged 11 months. The postmortem condition was as follows. There was tuberculosis of the left lung which had spread from caseous left tracheal and bronchial glands ; there was also acute general tuberculosis. There were caseous nodules in the submaxillary and cervical glands on both sides. Both tonsils were normal in size. The right tonsil contained a few not very typical giant cells. The left tonsil on section showed a small apparently caseous area, which under the microscope was seen to be composed of many typical giant-cell systems involving several of the follicles and a surrounding area of necrosis. Tubercle bacilli were present in some of the giant cells. Owing to the fairly advanced tuberculosis of the left tonsil and to the fact that it was also the left cervical, left tracheal, and left bronchial glands that were chiefly affected, it may possibly have been the case that the original entry was through the tonsil.

CASE 14 - The patient was two years of age. The postmortem condition was as follows. There were old caseation of the right tracheal glands and old fibrosis with some caseation of the right cervical glands with acute miliary tuberculosis. The right tonsil was enlarged and the left was atrophied but otherwise healthy.

CASE 15. - The patient was four years of age. The postmortem condition was as follows. There were very old caseation of the right tracheal glands and recent tubercle of the intestines and meninges. Both tonsils were quite healthy.

CASE 16. - The patient was three years of age. The postmortem condition was as follows. There were caseous thoracic glands, especially on the right side, and cavities in both lungs, intestinal ulceration with some caseation of the meserteric glands, and careous masses in the brain. The cervical glands were enlarged and above the right clavicle there were some very old fibro-caseous glands. Both tonsils were healthy.

CASE 17. - The patient was aged one year. The postmortem condition was as follows. There was caseation of the thoracic and mesenteric glands. There were cavities in the right lung, intestinal ulceration, and general tuberculosis. One cervical gland was caseating. Both tonsils were small but healthy.

Of these 17 cases, therefore, seven showed evidence of tuberculosis of the tonsils when examined microscopically but only three exhibited any naked-eye evidence of the disease. Of these three one showed ulceration, another scarring, and the third a caseous spot. Out of five cases where the tonsils were hypertrophied only two showed tubercle, the remaining tuberculous lesions being found in tonsils of normal size. Case 13 is the only one having any claims to consideration as a primary tonsillar infection and that case is very doubtful. The remaining cases were certainly all secondary to lesions elsewhere, the infection of the tonsils having been by the blood in five and in the other case probably by the sputum. In Cases 4, 8, and 14 where at the necropsy it seemer likely that the bacilli bad entered originally through the tonsils no evidence of tubercle could be found in them. The parts of the tonsils which were the seats of the lesions were usually the lymphoid follicles not far from the epithelial surface, but in no instance was I able to trace bacilli in from the crypts or surface of the tonsils. With regard to the ages of the cases it will be seen that two occurred in the first year of life, two in the second, and one in each of the third, fourth, and fifth years. Goerdeler ${ }^{10}$ has met with several under six months and Latham one at the age of three months.

It has surprised me on investivation to find how few cases of tubercle have been recorded in hypertrophied tonsils removed by operation. Purves Stewart ${ }^{11}$ described one case in 1895 and Friedmann found one case out of 54 that he examined, but Walsham and Wright out of a large number of cases did not come across a single instance. I cut sections of the hypertrophied tonsils of two operation cases which had enlarged cervical glands but found no trace of tubercle in either case. Altogether, some 200 cases seem to have been examined microscopically and only two cates of tubercle were found. Dieulafoy was more successful by inoculation as he found tubercle in eight out of 61 cases by this method, but since he did not in his experiments exclude any tubercle bacilli which might have been present free in the crypts his results are not quite so valuable as they would otherwise have been. It seems fairly reasonable to conclude that if hypertrophied tonsils removed by operation are tuberculous the infection has entered by those tonsils, for otherwise symptoms of serious disease could hardly fail to be noticed.

The belief which has of late years steadily been gaining ground-namely, that the tonsils are one of the most important channels by which the tubercle bacilli enter the system in childhood--has many supporters, amongst them Woodhead, ${ }^{12}$ Latham, and Aufrecht. Indeed, Aufrecht ${ }^{13}$ goes so far as to say that this happens in practically every case of tuberculosis at any age. He contends that the bacilli pass through the tonsil to the cervical glands and from them directly into the blood stream. It seems hardly likely, how. ever, that they would frequently pass throngh the tonsils without leaving behind some lesion which, by its chronicity, age, or extent (compare Case 13), would give some idea of its primary nature. In view of the small number of primary tonsil cases described compared with the total number of cases investigated $I$ do not think we are justified in going further than to say that the tonsil is a recognised channel of infection, and the evidence seems strongly against Aufrecht's contention.

From these cases and from the investigations of others the following conclusions may reasonably be drawn: (1) that tuberculosis of the tonsils, especially in cases with tubercle elsewhere, is fairly common, though the disease is usually latent; (2) that tonsil tuberculosis may be primary and, indeed, the only seat of the disease in the system, though this is rarely the case ; (3) that the usual method of infection is by the blood stream in children from an older focus elsewhere ; (4) that infection also may occur by the sputum in children; (5) that when the tonsils are tuberculous the corresponding cervical glands become affected; and (6) that sometimes where it is probable that the infection entered throngh the tonsils they were quite healthy but the adjacent cervical glands were tuberculous.

Dover.

\section{THE PROPHYLACTIC ACTION OF GARLIC AGAINST TUBERCULOUS DISEASES.}

\section{BY DR. GIULIO CAVAZZANI.}

AFTER the favourable results obtained in treating pulmonary phthisis by means of garlic, which I published for the first time in $1901^{1}$ and which were confirmed later by further statements of mine and of others, ${ }^{2} I$ thought it might be useful to see if garlic would also have a favourable effect on the course of other tuberculous infections in animals for experimentation and, eventually, if it would demonstrate a specific action against phthisical diseases. The question is of such vital importance that, having obtained favourable results from the first researches, I think it is my duty to make them known immediately in order to provoke dis. cussion and to stimulate research by which if my purely

11 Purves Stewart: Brit. Med. Jour., Mav, 1895.

12 Woorhead :

13 Aufrecht : Journal of Tuberculosis, Asheville, N.C., April, 1903.

1 G. Carazzani: L'Allium Sativum nella Cura della Tubercolosi Polmonare, Suppl. Policlinico, April, 1900.

P. Piccinini : Di un Nuovo Preparato dall' Allium Sativum, Corriere Sanitario, 1901. G. Carazzani : L'Aglio nella Cura della Tubercolosi Polmonare, Gazzetta Medica Lombarda, 1902. L. Sacchi: Nuove Osservazioni sull Efficacia Terapeutica ecc., Milano, 1902. G. Cavazzani L'Uso dell Aglio nella Terapia della Tubercolosi ecc, XIIe. Congresso Medico Internaziovale, Roma, 1902 G. Gennari Deplano : Tubercolosi Cura Radic le dela Tubercolosi Polmonare, Gazzetta Internazionale di Cura Radicte
Medicina, 1903. 
objective statements were confirmed, a therapeutic and civil problem which is perhaps the greatest one of our age would be solved.

About the end of June, 1903, I took eight guinea-pigs, six of which had been submitted to a preventive treatment for a fortnight, each swallowing daily 006 gramme (one grain) of garlic juice. After having dried and powdered expectorated mucus from tuberculou; patients I insuffited a small quan tity of this material into the larynx of each guinea-pig The animals so treated were kept for two days in a room impregnated with the same powder. Two guinea-pigs were kept as controls throughou's the experiment. Three of the remaining six were given the above-mentioned quantity of garlic for a fortnight and the other three were given similar amount till the end of September. I killed the animals in the first week of October.

The results of the necropsies were that the abdominal organs and the lymphatic system of the two guinea-pigs used for control were completely filled throughout with tuberculous formations in different stages of development. The microscopic examination of some tubercles proved the presence of Koch's bacillus. In the bodies of the three animals which had been treated with garlic for one month I found from 10 to 20 small tubercles, some of them in the liver and some in the spleen. The examination of the tubercles did not reveal the presence of Koch's elements, but instead it showed the presence of numerous fibres of young connective tissue. In the bodies of the other three guinea-pigs, those which had been treated with garlic up to the end of the experiment, I could find no tuberculous formations though the most minute examination was made The small number of animals used in the experiment forbids the drawing of conclusions.

If these results should be confirmed by further researches, which I have already begun, it would be proved that garlic prevents at least guinea.pigs from contracting tuberculous diseases through breathing the germs. As this seems to be the commonest way of contracting phthisis, and if we may consider animal pathology in the same light as human, it might mean the discovery of a method for preventing consumption.

Venice.

\section{Climital allotes:}

MEDICAL, SURGICAL, OBSTETRICAL, AND THERAPEUTICAL.

\section{NOTES OF A CASE OF HEMATURIA DUE TO THE} HAMORRHAGIC DIATHESIS. ${ }^{1}$

\section{By H. B. A. Pearson, L.R.C.P. Lond., M.R.C.S. ENG.}

THE patient, who is an unmarried female, 40 years of age, has been suffering from an attack of hæmaturia with variable losses of blood ever since Christmas, 1901. Her urine is acid in reaction; on standing it looks like beef-tea with sediment at the bottom and, as would be expected, it contains albumin. Under the microscope blood cells in large numbers and blood casts are seen. During the attack she has suffered from pain in the region of the right kidney, spasmodic in character and passing down in the direction of the right ureter to the bladder. About Christmas, 1902, pain began to be felt in the region of the left kidney, also spasmodic in character and passing down in the direction of the left ureter to the bladder, giving an impression that for the first 12 months the right kidney only was in fault. Menstruation is regular but prolonger to eight days ; 20 diapers are used and become well soaked. Bright coloured blood has been vomited but there has not been any symptom to suggest either hæmoptysis (there is no cough or expectoration) or hæmatemes is due to gastric ulcer, or even a varic se condition of the throat. Bright.coluured blood has been passed from the bowel but like so many of her sex the patient suffers from constipation and the passage of hardened fæces over the mucous membrane would be sufficient to account for this. She suffers from a rash, pinkish red in colour,

The patient was shown at a meeting of the Snuth-West London Medical Society in April, 1903. See THE LANCET of April 18th, p. 1105. fading into yellow, following the lines of the lower inter costal nerves. This is probably nervous in origin and traceable to the two kidneys as it cccurs on both sides. She has not had any rash of a petechial or purpuric character neither has she suffered from epistaxis, hæmatomata, or swelling in the joints due to hæmorrhage.

The family history is as follows. 'The patient's paternal grandmother died suddenly at the age of 28 years from hæmorrhage. The father, son of the above, died at the age of 60 years from hæmorrhage into the brain or meninges after an illness of 24 hours' duration; he had no brothers, but his three sisters all died suddenly under the age of 30 sears from bæmorrhage; one of the sisters had three children, all of whom died young from hæmorrhage. The patient, his daughter, lost one brother at the age of 15 years from beart disease and hæmorrhage ; one sister, aged 24 years, died suddenly with vomiting of blood, and another sister, aged five months, bled to death. She has five sisters living, all in good health except that one of them in her confinements has ante- and post partum hæmorrbage. She has one brother living, in good health and not liable to hæmorrhage. One of her sisters lost one boy, aged one vear and eight months, one girl, aged two years and seven months, and one girl, aged five years, from hæmorrbage. Her mother's family was healthy and not liable to bæmorrbage. The patient's first attack of hæmaturia occurred in 1894 ; it was caused by mental worry due to the death of her father and lasted for eight months. The second attack came on in 1899 , after the death of a niece, and lasted for three months. She has always suffered from vomiting on the slightest provocation. She has had measles, whooping cough, pleurisy, and congestion of the liver. The cause of the hremorrbage is evidently associated with some abnormal condition affecting the kidney or its hilum, as I have washed out the bladder on three different occasions with negative results.

This class of c ase seems to be rare. According to American records not one case was reported in ten years, but Grandidier, on the other hand, has collected references to a considerable number, of whom only a small minority reached maturity. The family history of this patient is at variance with the doctrine currently taught-namely, that the females usually transmit the diathesis to their male children. Evidently in this case the paternal grandmother transmitted it to her three daughters who all died from it under the age of 30 years, and through her son to bis daughters. This family history is certainly worth studying and also being recorded. The patient herself personally does not give any clue as to what she is suffering from and is able to carry on her occupation. Hot articles of food, however, increase the hæmaturia, so she is practically limited to food taken cold. She feels better in cold than in hot weather. New Wandsworth, S.W.

\section{OPERATIVE TREATMENT OF A PERFORATED GASTRIC ULCER.}

By JoHn H. Tonking, M.B. Loni), L.R.C.P. LoND, M.R.C.S. ENG.,

SURGEOY TO THE WIST COBNWALL MINERS', WOMEN'S, AND CHILDREN'S HOSPITAL.

THE patient whose case is now described is a single woman, 39 years of age. For about 18 months she had suffered from symptoms of gastric ulcer and usually con. fined herse $f$ to a special diet but with occasional lapses, one of which occurred on the evening of Oct. 21st, when she partook of potted tongue. Early on the following morn. ing she was awakened by violent internal pain which was agonising when $\mathrm{I}$ saw her at $9 \mathrm{~A}$ M. Her abdomen was then absolutely rigid but there was no vomiting. I thought it advisatie not to give morphine but I aoministered one thirtieth of a grain of nitrate of strychnine hypodermically and communicated with Dr. Frank Hichens of Redruth, who saw the patient with me at $11 \mathrm{~A} . \mathrm{M}$. and concurred in the diagrosis of perforated gastric ulcer. Morphine (a quarter of a grain) was then given and the patien was removed to the West Cornwall MIiners', Women's, and Childrt n's Hnspital at Redrutb, a distance of three miles. Here at 2 P.M - i.e. within 12 hours of the perforationDr. W. Blackwood administered ether and I with the help of Dr. Hichens cut down on the stomach. The anterior wall midway between the lesser and the greater 